\title{
Różne aspekty wielokulturowości z perspektywy nauczyciela akademickiego. Dobre praktyki
}

\section{KEY WORDS}

multiculturalism in the group of students; community language: good practises

\begin{abstract}
Bogdanowicz Izabela, Różne aspekty wielokulturowości z perspektywy nauczyciela akademickiego. Dobre praktyki [Various Aspects of Multiculturalism in a Group of Students. Good Practices]. Kultura - Społeczeństwo - Edukacja nr 2(10) 2016, Poznań 2016, pp. 163-180, Adam Mickiewicz University Press. ISSN 2300-0422. DOI 10.14746/kse. 2016.10.13.

The article presents ten selected practises, which give good teaching results in student groups that include foreigners. Among good practices are proprietary solutions, such as specially designed team-work cards (tool), organisation of moderated discussions and organisation of work in teams (techniques).

The author draws conclusions that are not supported by the research. However, they may have practical value for people who teach classes in multicultural student environment. Good practices, an outcome of author's professional experience, may also serve as a starting point for discussion about multiculturalism in the student community. Identification of common problems, in conjunction with presentation of good practices, allows a flexible approach to the readers; leaves them space to develop their own solutions, according to the conditions.
\end{abstract}

W ciągu zaledwie dekady internacjonalizacja przestała być marginalnym doświadczeniem wielu uczelni w Polsce. Na marginesie zaś zdaje się pozostawać przygotowanie nauczycieli akademickich do zajęć ze studentami zagranicznymi, w kontekście wielokulturowości. Z tego względu pożądana jest wymiana doświadczeń, zwłaszcza w formie prezentacji dobrych praktyk, które sprawdziły się $\mathrm{w}$ pracy ze studentami w grupach wielokulturowych.

Umiędzynarodowienie uczelni w Polsce jako kryterium ich oceny znalazło się w rankingu firmowanym przez „Perspektywy” w 2006 roku, o rok wyprzedza- 
jąc wprowadzenie tego wskaźnika do ministerialnego algorytmu rozdziału środków finansowych dla uczelni (Siwińska, 2012). W pierwszym programie umiędzynarodowienia szkolnictwa wyższego (2015 r.) akcentowano je jako jedno $\mathrm{z}$ najważniejszych wyzwań ${ }^{1}$. Program zawiera różne zadania dla uczelni, ale „podniesienie kompetencji kadry (...) w zakresie rozumienia różnic międzykulturowych i udzielania wsparcia studentom zagranicznym" jest dopiero w specjalnych projektach różnych uczelni (często dofinansowywanych $\mathrm{z}$ funduszy unijnych) ${ }^{2}$.

Doświadczenie autorki pokazało, że praca ze studentami zagranicznymi jest dużym wyzwaniem (temat nauczania cudzoziemców pojawia się w wielu publikacjach różnych autorów, ale adresowany jest do nauczycieli ze szkół na poziomie edukacji poprzedzającym studia ${ }^{3}$ ). W środowisku studenckim wielokulturowość nie jest rzeczywistością bezproblemową. Oto przykład: w edycji w roku 2016 Konkursu Reporterskiego „Widoki”4 w gronie laureatów był autor reportażu zainspirowany ogłoszeniem wyników naboru na specjalizację telewizyjną. Co trzeci student zagraniczny (głównie z Ukrainy, Białorusi, Litwy) w 21-osobowym gronie osób przyjętych na specjalizację to fakt, na który wielu studentów krajowych zareagowało, w komentarzach do informacji, tzw. hejtem (Szczygieł, 2016).

To jednostkowy przykład, ale mimo wszystko postawy młodych ludzi, i to studentów, zaskakują, skoro faktem jest prezentowana już kilkanaście lat temu przez Kazimierza Szmyda tradycja polskiej pedagogiki wielokulturowej (Szmyd, 2003). Wymowny jest tytuł wielotomowej serii „Stan Badań nad Wielokulturo-

\footnotetext{
${ }^{1}$ Kierunki działań: Zadania dla uczelni. Dostosowanie obsługi do potrzeb studentów zagranicznych i poszerzanie umiejętności kadry akademickiej, [w:] Program umiędzynarodowienia szkolnictwa wyższego, 2015, s. 17, http://www.nauka.gov.pl/aktualnosci-ministerstwo/program-umiedzynarodowienia-szkolnictwawyzszego.html.

${ }^{2}$ Przykład: Warszawski Uniwersytet Medyczny (WUM) przez prawie półtora roku (1.01.2015-31.05.2016) realizował projekt, którego głównym celem było „(...) podniesienie jakości i efektów kształcenia studentów zagranicznych WUM poprzez zapewnienie im wsparcia psychospołecznego i ułatwienie integracji ze środowiskiem lokalnym, głównie akademickim”. Projekt miał umożliwić m.in. „(..) podniesienie kompetencji kadry WUM w zakresie rozumienia różnic międzykulturowych i udzielania wsparcia studentom zagranicznym". Zob. [b.a.], Adaptacja Kulturowa, Integracja i Wsparcie Psychospołeczne dla Studentów Zagranicznych, Fundusz Stypendialny i Szkoleniowy, http://www.fss.org.pl/node/691.

${ }^{3}$ Przykłady (poza licznymi publikacjami Jerzego Nikitorowicza): B. Głodzik (2002), Przygotowanie nauczycieli do edukacji wielokulturowej, [w:] M. Chodkowska (red.), Wielowymiarowość integracji $w$ teorii i praktyce edukacyjnej, Lublin, s. 209-212; B. Januszko (2007), Nauczyciel i uczeń w systemie edukacji wielokulturowej [w:] M. Karwowska-Struczyk, E. Słodownik-Rycaj (red.), Pedagogika małego dziecka. Wybrane zagadnienia, Warszawa, s. 81-98; E. Kowalska (2003), Kształcenie międzykulturowe jako próba odpowiedzi pedagogiki na problemy współczesnego społeczeństwa wielokulturowego, [w:] J. Kuźma, J. Morbitzer (red.), Nauki pedagogiczne w teorii i praktyce edukacyjnej, t. 2, Kraków, s. 12-17.

${ }^{4}$ Konkurs Reporterski „Widoki”, [inicjatywa studentów dziennikarstwa UW], https://www.wdib.uw. edu.pl/samorzad-studencki-wdiib-uw.
} 
wym Dziedzictwem Dawnej Rzeczypospolitej”. Jeśli nawet owa wielokulturowość dziedzictwa sprzed wieków nie ma wpływu na współczesne postawy wobec cudzoziemców, to i tak było dosyć czasu, by oswoić się z obecnością studentów zagranicznych. Zaledwie w ciągu siedmiu lat (2004-2011) ich liczba na uczelniach w Polsce wzrosła prawie trzykrotnie (liczba studentów polskiego pochodzenia jest niemal stała) (Szkolnictwo wyższe w Polsce..., 2013: 25).

Jednocześnie w polszczyźnie istnieje wzmocnienie obcości: osoby z zagranicy to cudzo-ziemcy, obco-krajowcy; a przecież już Znaniecki (1931: 18) akcentował, że obcość to „(...) cecha względna, którą ten sam człowiek lub ta sama klasa ludzi niezależnie od swych własnych modyfikacji może posiadać w pewnych warunkach, nie posiadać $\mathrm{w}$ innych". Różne aspekty wielokulturowości w języku prezentują autorzy publikacji z serii "Język a Kultura” (Dąbrowska, Burzyńska-Kamieniecka, 2006), co jest oczywiste w sytuacji, gdy „[w]spółczesna popularność, czy nawet moda na termin wielokulturowość sprawiają, że staje się on coraz bardziej niejednoznaczny. Jest to tym istotniejsze, gdyż nigdy nie przyjęto podstawowego znaczenia tego terminu, od którego można byłoby wywodzić wszystkie jego rozumienia” (Śliz, Szczepański, 2011a: 14).

Tabela 1. Umiędzynarodowienie uczelni w Polsce - zmiany wskaźników w roku akademickim 2014/2015 i 2015/2016. Źródło: opr. własne. Na podstawie: Siwińska B. (2015), Już ponad 46 tysięcy studentów zagranicznych $w$ Polsce, http://www.perspektywy.pl/portal/index.php?option=com_content\&view =article\&id=2221:juz-ponad-46-tysiecy-studentow-zagranicznych-w-polsce\&catid=24\&Itemid=119; Główny Urząd Statystyczny, Szkolnictwo wyższe, stan w dniu 30.XI. 2015 r. - dane wstępne, http://stat.gov.pl/obszarytematyczne/edukacja/edukacja/szkolnictwo-wyzsze-stan-w-dniu-30-xi-2015-r-dane-wstepne,8,3.html

\begin{tabular}{|c|l|c|c|c|c|}
\hline Lp. & \multicolumn{1}{|c|}{ Studenci w Polsce - wskaźniki } & $\mathbf{2 0 1 4 / 2 0 1 5}$ & Zmiana $^{*}$ & $\mathbf{2 0 1 5 / 2 0 1 6}$ & Zmiana $^{*}$ \\
\hline 1. & Łączna liczba studentów w Polsce & 1469386 & spadek o $\sim 80$ tys. & 1405133 & spadek o $\sim 64$ tys. \\
\hline 2. & $\begin{array}{l}\text { W tym studenci zagraniczni } \\
\text { (odsetek studentów zagranicznych) }\end{array}$ & $\begin{array}{c}46101 \\
(3,1)\end{array}$ & $\begin{array}{c}\text { wzrost o } \sim 36 \text { tys. } \\
\text { (b.d.) }\end{array}$ & $\begin{array}{c}57119 \\
(4,1)\end{array}$ & $\begin{array}{c}\text { wzrost o } \sim 11 \text { tys. } \\
(5,1)\end{array}$ \\
\hline 3. & $\begin{array}{l}\text { Pochodzenie studentów zagranicz- } \\
\text { nych (liczba krajów) }\end{array}$ & 158 & bd. & 157 & $* *$ \\
\hline 4. & Studenci z Ukrainy (w tys.) & $\sim 23$ & wzrost o $\sim 8$ & $\sim 30$ & wzrost o $\sim 7$ \\
\hline 5. & $\begin{array}{l}\text { Ukraińcy wśród studentów zagra- } \\
\text { nicznych w Polsce (w tys.) }\end{array}$ & ponad 50 & wzrost o $\sim 8$ & ponad 53 & wzrost o $\sim 3$ \\
\hline 6. & $\begin{array}{l}\text { Druga największa grupa studentów } \\
\text { zagranicznych w Polsce: Białorusini }\end{array}$ & $4-118$ & bd. & 4615 & $\star *$ \\
\hline
\end{tabular}

* zmiana w stosunku do poprzedniego roku akademickiego

${ }^{*}$ zmiana statystycznie nieistotna

bd. - brak danych 
Z badań stosunku Polaków do innych narodów wynika, że „(...) Ukraińcy budzą największe emocje - najrzadziej wyrażana jest wobec nich obojętność, częściej zaś sympatia lub niechęć"; niewielka jest przewaga sympatii do Ukraińców nad niechęcią do nich (odpowiednio 36 i 32\%); „(w) latach dziewięćdziesiątych ubiegłego wieku i pierwszych latach obecnego stosunkowo najmniejszą sympatię i zarazem największą niechęć deklarowaliśmy wobec Ukraińców, jednak wraz z nadejściem «pomarańczowej rewolucji» nasz stosunek do nich poprawił się" (Omyła-Rudzka, 2015).

Nową, złożoną sytuację, podkreślały dane statystyczne: w roku akademickim 2014/2015 w Polsce było, w porównaniu do roku wcześniejszego, ponad pięćdziesiąt procent więcej studentów z Ukrainy (zob. tab. 1).

Problemem, który wydawał się wart analizy pod kątem wielokulturowości w praktyce nauczyciela akademickiego (dziennikarstwo na uczelniach na dwóch najwyższych poziomach: na uniwersytecie oraz na akademii), była specyfika zajęć typu ćwiczenia - z udziałem studentów zagranicznych oraz w grupie wyłącznie takich studentów. Oczywista była refleksja: Czy studentów zagranicznych należy traktować inaczej niż krajowców? Jeśli tak, to dlaczego? Po co? Jak to robić? Perspektywa czasowa obejmowała zajęcia w ciągu kilku lat, przed rokiem akademickim 2014/2015, natomiast kompleksowe zastosowanie praktyk nastąpiło po raz pierwszy w roku akademickim 2014/2015.

Motywacją do działań w celu wypracowania dobrych praktyk była troska o jakość zajęć poprzez rozwiązanie problemów, które powtarzały się w grupach ze studentami zagranicznymi. Adekwatne do rzeczywistości było przekonanie o potrzebie osiągnięcia stanu wielokulturowości rozumianej jako „współistnienie wielu różnych kultur w określonej przestrzeni społecznej”, by realne było przejście, poprzez międzykulturowość („,wzajemne uczenie się kultur”, „przenikanie się

Tabela. 2. Studenci zagraniczni na uczelniach w Polsce w 2015 r. Źródło: opr. własne na podstawie [b.a.] Dane wstępne dotyczące szkolnictwa wyższego za 2015 rok, Główny Urząd Statystyczny. Portal Informacyjny, http://stat.gov.pl/obszary-tematyczne/edukacja.

\begin{tabular}{|c|l|r|c|}
\hline \multicolumn{1}{|c|}{ Lp. } & \multicolumn{1}{|c|}{ Studenci } & Liczba & Opis \\
\hline 1. & z całego świata & 57119 & $100 \%$ \\
\hline 2. & w tym z Europy & 47591 & $83 \%$ studentów z całego świata \\
\hline 3. & w tym z Ukrainy & 30589 & $64 \%$ studentów z Europy \\
\hline \multicolumn{3}{|c|}{ W tym cudzoziemcy polskiego pochodzenia } \\
\hline 4. & z całego świata & 7576 & $100 \%$ \\
\hline 5. & w tym z Europy & 7113 & $94 \%$ studentów z całego świata \\
\hline 6. & w tym z Ukrainy & 3616 & $51 \%$ studentów z Europy \\
\hline
\end{tabular}


i wymiana wartości różnych kultur”), do transkulturowości, pojmowanej jako „przenikanie elementów różnych kultur, czego rezultatem jest nowa jakość kulturowa" (Śliz, Szczepański, 2011b: 13).

Spojrzenie perspektywiczne, oparte na kryteriach społeczno-politycznych, jest poza zakresem tematycznym niniejszego tekstu, ale warto zwrócić uwagę na kilka danych (zob. tab. 2).

Nie bez znaczenia są realne uwarunkowania, szczególnie te, które są od nas niezależne, ale dla nas istotne:

[1] przewiduje się, że do roku 2020 podwoi się liczba osób studiujących za granicą (obecnie w skali świata: 4,5 mln) (Siwińska, 2015);

[2] Departament Współpracy Międzynarodowej w Ministerstwie Nauki i Szkolnictwa Wyższego przygotował stronę internetową www.go-poland.pl dla osób zainteresowanych studiami w Polsce ${ }^{5}$, a mimo to ocenia się, że „Polska jest, obok Chorwacji, najmniej umiędzynarodowionym krajem Unii Europejskiej i jednym z najsłabiej umiędzynarodowionych w OECD" (Siwińska, 2015);

[3] już ponad dekadę temu stwierdzono, że wyższy niż u wschodnich sąsiadów poziom życia społeczeństwa polskiego ma wpływ - od roku 1990 na wzrost liczby imigrantów (Mucha, 2004: 214), a to z czasem może mieć związek ze wzrostem liczby zagranicznych studentów.

Znaczenie ma, ze względu na niekorzystne prognozy demograficzne dla Polski ${ }^{6}$ i spadek liczby studentów (zob. tab. 3), zainteresowanie osób z zagranicy studiami w Polsce oraz zatrzymanie na rynku pracy cudzoziemców, także absolwentów uczelni w Polsce.

Tabela 3. Studenci krajowi i zagraniczni (łącznie) na uczelniach w Polsce. Źródło: opr. własne na podstawie [b.a.], Szkolnictwo wyższe w Polsce 2013, op. cit.

\begin{tabular}{|c|c|c|c|}
\hline Lp. & Rok & Liczba & Opis stanu liczbowego \\
\hline 1. & 1999 & 390429 & $100 \%$ \\
\hline 2. & 2001 & 1584804 & wzrost o $406 \%$ (w por. z 1999 r.) \\
\hline 3. & 2015 & 1405133 & spadek o $11 \%$ (w por. z 2001 r.) \\
\hline
\end{tabular}

${ }^{5}$ Strona internetowa o studiach w Polsce dla obcokrajowców, Ministerstwo Spraw Zagranicznych, Wspótpraca dwustronna, Wspótpraca naukowa, http://www.paryz.msz.gov.pl.

${ }^{6}$ Ludność w Polsce: 2014 - 38461 752. Prognozy: spadek. Poniżej: 38 mln - 2022 r.; 37 mln - 2032 r.; $36 \mathrm{mln}-2038$ r.; $35 \mathrm{mln}$ - 2044 r.; $34 \mathrm{mln}$ - 2050 r. Więcej: GUS - Prognoza ludności na lata 2014-2050 (opracowana 2014 r.), [publikacja:] 01.10.2014 r., Obszary tematyczne. Ludność. Prognoza ludności, http://stat.gov.pl/obszary-tematyczne/ludnosc/prognoza-ludnosci/. 
Z badań wynika, że „(...) dla części studentów Polska jest krajem pośrednim, $\mathrm{w}$ którym mogą zdobyć edukację na określonym poziomie, jednak nie jest to ich poziom docelowy - ten zamierzają uzupełnić w innych krajach - można przypuszczać, że w innych krajach Europy Zachodniej (...)” (Trzciński, 2015: 199). Przyjazne studia sprzyjają pogłębianiu więzi z naszym krajem, a to może przesądzić o zmianie decyzji o traktowaniu Polski jako kraju pośredniego, a nie docelowego. Najnowsze badania skłaniają do zgody z opinią, że „(...) konieczne będzie $\mathrm{w}$ najbliższych latach podjęcie dodatkowych działań służących asymilacji studentów z Ukrainy, ale również z Białorusi, ze społeczeństwem polskim" (Trzciński, 2015: 199). Ta asymilacja odbywa się we wszystkich środowiskach, także na uczelniach.

\section{Dziesięć dobrych praktyk}

Praktyka wskazywała na złożoność problemu wielokulturowości. Przykładem może być wybór dziennikarstwa jako kierunku studiów w obcym kraju. Problemem okazała się obcość kodów kulturowych: nawet te, które są co najmniej kojarzone przez studentów krajowych, przeważnie nic nie mówią studentowi zagranicznemu (trzeba przyznać, że tego typu braki wiedzy mieli też niektórzy studenci krajowi). W takim przypadku zaangażowanie w tok zajęć nie mogło być w pełni efektywne. Nie do przyjęcia byłoby jednak obniżenie poziomu zajęć wskutek dostosowania go do miernej wiedzy studentów. Jak wobec tego rozwiązać ten problem? Zdaniem autorki godne uwagi są dobre praktyki w formie zajęć adaptacyjnych (nie tylko językowych) ${ }^{7}$. Warto też przyjrzeć się efektom i skutkom drogi Amerykanów od koncepcji tygla kulturowego do tak zwanej podrzucanej sałatki (ang. tossed salady), co oznacza „(...) uznanie praw przedstawicieli odrębnych grup kulturowych do szukania własnych korzeni, kolorów i zachęcanie do dumy z własnej odrębności” (Zarzycka-Suliga, 1996: 282-283).

$\mathrm{Na}$ rozwiązanie oczekują też różne problemy formalne, w tym takie, jak na przykład nieobecność studentów zagranicznych w okresie wolnych dni świątecznych w ich kraju. Studenci wyjeżdżali, a post factum pisali maile z informacją, że mają obowiązek uzyskać, od osoby prowadzącej ćwiczenia, zgodę na taką nieobecność. Doraźnym rozwiązaniem było poinformowanie studentów, że nieobecność planowana, na przykład $\mathrm{z}$ powodu świąt, powinna być wykorzystana w ramach limitu nieobecności na ćwiczeniach. Bez wątpienia nie było to rozwiązanie idealne, ale okazało się skuteczne. Dla innych problemów, zasadniczo rzu-

\footnotetext{
${ }^{7}$ Przykład: SWPS Uniwersytet Humanistycznospołeczny; studenci zagraniczni - 38 narodowości. Zajęcia adaptacyjne - informacja od prof. dr. hab. Pawła Boskiego w rozmowie autorki podczas konferencji naukowej 23.06.2016 r. na UW. Notatki własne autorki.
} 
tujących na efektywność zajęć, autorka znalazła rozwiązania praktyczne, które można określić jako dobre praktyki, ponieważ sprawdziły się w każdej grupie.

Dziesięć dobrych praktyk zostało wybranych spośród działań opartych na doświadczeniu osoby prowadzącej ćwiczenia (zob. tab. 4). Kolejność ich prezentacji nie jest tożsama $\mathrm{z}$ uszeregowaniem według ważności, ponieważ $\mathrm{w}$ profilaktyce zapobiegania konfliktom uwarunkowanym wielokulturowością nie ma nieważnych detali. Marian Golka (2010: 65) uważa, że odmienne zewnętrzne cechy dystynktywne „(...) przyczyniają się do wzajemnego postrzegania odmienności,

Tabela 4. Zajęcia z udziałem studentów zagranicznych - dobre praktyki (wybór). Źródło: opracowanie własne autorki na postawie materiałów z własnych zajęć.

\begin{tabular}{|c|c|c|c|c|c|c|}
\hline \multicolumn{6}{|c|}{ Problem } & Rozwiązanie problemu \\
\hline \multirow[b]{3}{*}{ Istota problemu } & \multicolumn{5}{|c|}{ Interesariusze } & \multirow[b]{3}{*}{ Dobra praktyka } \\
\hline & \multicolumn{2}{|c|}{ 1/ Studenci } & \multirow[b]{2}{*}{$\begin{array}{c}\text { 2/ Prowadzący } \\
\text { zajęcia }\end{array}$} & \multicolumn{2}{|c|}{ 3/ Inni (wybór) } & \\
\hline & $\frac{\sqrt[3]{\pi}}{\sqrt[\pi]{3}}$ &  & & 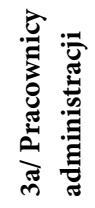 & 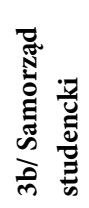 & \\
\hline Ludzkie słabości & $\mathrm{x}$ & $\mathrm{x}$ & $\mathrm{x}$ & $\mathrm{x}$ & $\mathrm{x}$ & Świadomość stereotypów i uprzedzeń \\
\hline Słabe współistnienie & $\mathrm{x}$ & $\mathrm{x}$ & $\mathrm{x}$ & $\mathrm{x}$ & $\mathrm{x}$ & Autoprezentacja mocnych stron \\
\hline $\begin{array}{l}\text { Zamykanie się we własnym } \\
\text { kręgu }\end{array}$ & $\mathrm{x}$ & $\mathrm{x}$ & $\mathrm{x}$ & $\mathrm{x}$ & $\mathrm{x}$ & Regulacje pracy w zespołach \\
\hline Niższy poziom aktywności & & $\mathrm{x}$ & $\mathrm{x}$ & & & $\begin{array}{l}\text { Szansa na wzrost aktywności: tzw. } \\
\text { wejściówki }\end{array}$ \\
\hline $\begin{array}{l}\text { Aktywność studentów kra- } \\
\text { jowych blokuje studentów } \\
\text { zagranicznych }\end{array}$ & $\mathrm{x}$ & $\mathrm{x}$ & $\mathrm{x}$ & & & $\begin{array}{l}\text { Integrator - rola w dyskusji mode- } \\
\text { rowanej }\end{array}$ \\
\hline $\begin{array}{l}\text { Imiona, nazwiska - obszar } \\
\text { wrażliwy }\end{array}$ & $\mathrm{x}$ & $\mathrm{x}$ & $\mathrm{x}$ & $\mathrm{x}$ & $\mathrm{x}$ & Szacunek dla imion i nazwisk \\
\hline $\begin{array}{l}\text { Nauczyciel akademicki } \\
\text { w obcym kraju - jak rodzic } \\
\text { zastępczy? }\end{array}$ & & $\mathrm{x}$ & $\mathrm{x}$ & $\mathrm{x}$ & $\mathrm{x}$ & $\begin{array}{l}\text { Wskazanie obszarów komunikowa- } \\
\text { nia się studenta zagranicznego na } \\
\text { uczelni }\end{array}$ \\
\hline Różne wartości & $\mathrm{x}$ & $\mathrm{x}$ & $\mathrm{x}$ & $\mathrm{x}$ & $\mathrm{x}$ & Informacja o prawie i etyce \\
\hline $\begin{array}{l}\text { Niska efektywność pracy } \\
\text { w zespołach }\end{array}$ & $\mathrm{x}$ & $\mathrm{x}$ & $\mathrm{x}$ & & & Karta pracy zespołu \\
\hline $\begin{array}{l}\text { Ograniczone możliwości } \\
\text { rozwoju kompetencji języ- } \\
\text { kowych }\end{array}$ & & $\mathrm{x}$ & $\mathrm{x}$ & & & Przyjazny język obcy \\
\hline
\end{tabular}


z różnymi tego skutkami”. $\mathrm{Z}$ doświadczenia autorki wynika, że te pozorne drobiazgi (np. specyfika makijażu studentek zagranicznych, styl ubierania się) mogą stać się zarzewiem konfliktu, a co najmniej źródłem niechęci, często nieuświadomionej. Zbigniew Benedyktowicz (2000: 24) określa „swoich” jako tych, którzy dzięki znajomości zasad gry społecznej (konwencje, niepisane reguły itp.) mogą w niej uczestniczyć. Dla „obcych” te zasady nie są oczywiste, a inny wygląd, język czy zachowanie nie ułatwiają wejścia do owej gry, co w konsekwencji może prowadzić do izolacji czy odrzucenia.

Warto zauważyć, że w przypadku studentów zagranicznych interesariuszami są nie tylko osoby prowadzące zajęcia, ale także pracownicy administracyjni czy przedstawiciele samorządu studenckiego, jak również władze uczelni na wszystkich szczeblach. W tym miejscu należy podkreślić, że specyfika studiów dziennikarskich przejawia się między innymi w tym, że ćwiczenia i zajęcia warsztatowe prowadzą nie tylko nauczyciele akademiccy, ale również zapraszani przez uczelnię praktycy, których nie ominą problemy wynikające $\mathrm{z}$ wielokulturowości.

Bianka Siwińska, autorka raportu Studenci zagraniczni w Polsce 2014, wyraża przekonanie, że „[z]arówno środowisko akademickie, jak i opinia publiczna, władze samorządowe oraz osoby odpowiedzialne za politykę publiczną państwa w obszarze szkolnictwa wyższego powinny ze szczególną uwagą śledzić te nastroje i proponować rozwiązania wspierające właściwą integrację studentów z Ukrainy w życie uczelni i społeczności lokalnej” (Siwińska, 2015). Poziom wpływu interesariuszy i ich zainteresowania jest różny, adekwatnie do stanu rzeczy na danej uczelni.

\section{Dobra praktyka 1: Świadomość stereotypów i uprzedzeń}

Wzmocnieniem tej sytuacji, wyjątkowo trudnej dla nauczycieli akademickich, prowadzących zajęcia $\mathrm{w}$ formie ćwiczeń, jest, dostrzegalna na niektórych uczelniach, monokultura ukraińska. Bianka Siwińska zwraca uwagę: „W związku ze stałym, dynamicznym przyrostem liczby Ukraińców, coraz powszechniej mówi się o zjawisku «ukrainizacji» polskich uczelni. Na tym tle w ostatnim roku pojawiły się w kilku ośrodkach akademickich incydenty o podłożu ksenofobicznym" (Już ponad 57 tysięcy...). Być może tzw. ukrainizacja polskich uczelni to zaledwie wierzchołek góry lodowej, skoro oficjalne dane przeczą zauważalnym w publicznym dyskursie opiniom o stałej monokulturowości Polski, a więc i niewielkim odsetku studentów zagranicznych, zwłaszcza spoza Europy ${ }^{8}$.

\footnotetext{
${ }^{8}$ W Polsce w ostatnich dwóch latach wzrosła liczba studentów z Afryki - 1197, o 478; z Arabii Saudyjskiej - 854 i Turcji - 1205. Dane wstępne dotyczące szkolnictwa...
} 
Jak oceniają Anna Śliz i Marek S. Szczepański, „[n]ie bez znaczenia pozostają tutaj zakorzenione $\mathrm{w}$ świadomości wielu ludzi stereotypy, których potwierdzenia szukamy w rzeczywistym kontakcie z mniejszością narodową, etniczną czy jakąkolwiek inną, co może prowadzić do antagonizmu, a nawet konfliktu" (Śliz, Szczepański, 2011b: 11). „Wiedza o stereotypach i stosunku wobec innego”, jak brzmi tytuł jednego z rozdziałów książki Izabeli Czerniejewskiej, to podstawa, która wystarcza, by zdać sobie sprawę, z czego wynikają nasze uprzedzenia; kolejny krok to uświadomienie sobie złożoności problemu i konieczności zróżnicowania podejścia wobec różnych kategorii przybyszy z zagranicy - uchodźcy, imigranci, repatrianci (Czerniejewska, 2013).

Źródłem wielu problemów $\mathrm{w}$ relacjach $\mathrm{z}$ osobami z zagranicy są zwykłe ludzkie słabości, od których nie są wolni ani studenci, ani nauczyciele akademiccy. Przede wszystkim jest to postrzeganie inności jako czegoś obcego („oni” vs. „my”), ze wszystkimi, wynikającymi z takiej postawy, konsekwencjami. Istotne jest też przypisywanie i akcentowanie cech negatywnych (oni są "tacy”! - niewychowani, roszczeniowi itp.). Niekorzystna jest skłonność do uogólnień („oni” = „wszyscy”) w oparciu o jednostkowe przypadki, jak również zwracanie uwagi na detale, które są mniej istotne lub nieistotne $\mathrm{w}$ relacjach ze studentami krajowymi. Jeśli student, po uzyskaniu ponadstandardowej pomocy od innego studenta lub osoby prowadzącej zajęcia, nie powie „dziękuje”, to w odniesieniu do studenta zagranicznego pojawia się skłonność do bardziej krytycznej oceny (brak „dziękuje” = braki w kulturze osobistej studenta-krajowca, ale znacznie więcej u studenta zagranicznego). Od takich słabości blisko do uprzedzeń i dyskryminacji, do nietolerancji i ksenofobii .

Świadomość stereotypów i uprzedzeń daje konkretne korzyści: zmniejszenie ryzyka antagonizmów i konfliktów; większa szansa stworzenia atmosfery współistnienia opartej na wzajemnym zrozumieniu, co sprzyja szacunkowi oraz eliminowaniu postaw izolacji.

\section{Dobra praktyka 2: Autoprezentacja mocnych stron}

W obrębie monokultury można się spodziewać, że nie zaistnieje problem ze współistnieniem wewnętrznym, tymczasem w pozornie jednolitej grupie ukraińskiej dostrzegalne były przejawy braku wspólnoty i wręcz manifestacji odrębności osób z zachodniej i wschodniej części kraju. Łatwiejsze wydawały się relacje w grupie polsko-ukraińskiej, ponieważ tam można było się spodziewać problemów ze współistnieniem, a więc i przygotować się do nich. Samorząd studencki podejmuje różne działania w celu adaptacji kulturowej oraz integracji studentów;

\footnotetext{
${ }^{9}$ Międzynarodowa Konwencja ONZ w sprawie likwidacji wszelkich form dyskryminacji rasowej otwarta do podpisu w Nowym Jorku 7 marca 1966 r., w Polsce obowiązuje od 1969 r. Zob. Dz. U. z 1969 r., nr 25, poz. 187.
} 
przeważnie pokazywana jest specyfika, ale bez wyjaśniania różnic, które mogą stwarzać problemy w codziennych relacjach.

$\mathrm{W}$ warunkach rywalizacji (stypendia naukowe, ale również pozycja w grupie) sprawdziło się umożliwienie studentom zaprezentowania się koleżankom i kolegom tak, by zainteresować ich sobą w kontekście danego przedmiotu. Skłonienie do takiej refleksji procentowało: bywało odkryciem dla samego siebie, zwracało uwagę grupy. Krótka autoprezentacja na pierwszych zajęciach była taką szansą dla studentów zagranicznych, którzy nawet na portalach społecznościowych tworzyli własne gremia, a więc dla studentów krajowych pozostawali obcy. Wiedza o drugiej osobie sprzyja poznaniu i wzajemnemu szacunkowi, ale niezbędne zaufanie do obcego buduje się dłużej.

Korzyści z tej dobrej praktyki były nadspodziewane. Studenci krajowi zaczęli zwracać uwagę na osoby z zagranicy, których doświadczenie lub hobby wydało się atrakcyjne i warte poznania. Studenci zagraniczni zaś dziękowali za ten element zajęć po upływie czasu, gdy dostrzegli wartość autoprezentacji w relacjach ze studentami krajowymi.

\section{Dobra prakłyka 3: Regulacje pracy grupy w zespołach}

Na zajęciach typu ćwiczenia zdarza się, że niektórzy studenci krajowi nie lubią pracy $\mathrm{w}$ zespołach, ale $\mathrm{w}$ grupach $\mathrm{z}$ udziałem studentów zagranicznych były inne problemy: studenci unikali zespołów mieszanych, a osoba najlepsza w języku polskim wyręczała rodaków w realizacji zadania. Rozwiązanie problemu polegało na wprowadzeniu dwóch zasad odnośnie do składu zespołów: 1) skład zmienny (na kolejnych zajęciach); 2) skład mieszany (studenci krajowi i zagraniczni).

Zasady organizacji pracy w zespołach były opracowane w ramach kształtowania kompetencji społecznych, ale zostały zmodyfikowane między innymi $\mathrm{w}$ celu integracji studentów krajowych $\mathrm{z}$ zagranicznymi oraz ułatwienia udziału tych ostatnich w zajęciach. Aprobata zasad, po uprzednim wyjaśnieniu ich celowości, była jednogłośna, konsekwentne zaś ich przestrzeganie (na każdych zajęciach weryfikowanie podziału na zespoły) sprawiło, że przyjęte rozwiązanie okazało się korzystne dla całej grupy.

\section{Dobra praktyka 4: Szansa na wzrost akływności - tak zwane wejściówki}

Mimo upływu czasu widoczny był niższy, w porównaniu ze studentami krajowymi, poziom aktywności studentów zagranicznych. Nie sprawdzało się ani podawanie literatury przedmiotu (nawet ze wskazaniem stron), ani dowolność 
takiego wyboru. Rozwiązaniem problemu, przynajmniej w przypadku niektórych przedmiotów (i tematów), okazały się tzw. wejściówki. Na uczelniach technicznych tak zwane wejściówki zawsze pełniły rolę sprawdzianu przygotowania studenta do zajęć laboratoryjnych. Na takich kierunkach jak dziennikarstwo tzw. wejściówka może być sprawdzianem przygotowania do ćwiczeń, czyli znajomości pojęć czy terminów z literatury obowiązkowej na dany temat. Aby sprawdzanie, na początku zajęć, wejściówek nie zajęło zbyt dużo czasu, osoba prowadząca zajęcia musi dołożyć starań na etapie przygotowania ich i narzędzi do sprawdzenia.

Wejściówki mogą pełnić funkcję dyscyplinującą i/lub motywującą, ale przede wszystkim wspierającą studentów; w grupie ze studentami zagranicznymi ułatwiały przygotowanie się do zajęć, poczynając od terminologii i słów trudnych dla obcokrajowców. Tym samym wzrastała efektywność zajęć i satysfakcja studentów zagranicznych z udziału w ćwiczeniach.

\section{Dobra prakłyka 5: Integrator - rola w dyskusji moderowanej}

W dyskusji moderowanej często dominuje kilka osób, które potocznie określa się jako wygadane, zdolne do ogólnikowych wypowiedzi na każdy temat. Ta aktywność, tylko pozornie merytoryczna, bywa blokadą aktywności studentów zagranicznych. Odwołanie do wartości, apel o koleżeńskość, czyli dawanie pierwszeństwa wypowiedzi koleżankom i kolegom, którzy nie zabierali głosu, zazwyczaj nie wystarcza. Skutecznym sposobem aktywizacji dosłownie wszystkich obecnych okazało się wprowadzenie roli integratora. Ta rola, przyjmowana na ochotnika, na czas jednych zajęć, wiązała się $\mathrm{z}$ używaniem narzędzia $\mathrm{w}$ formie karty dyskusji moderowanej i stosowania triady zasad.

Integrator używał karty z graficzną formułą zapisu (układ miejsc na sali, nazwiska), która ułatwiała bieżącą orientację co do aktywności poszczególnych osób. Kartę przygotowywał sam, na początku zajęć (niektóre osoby przygotowywały taką kartę wcześniej, podkreślając w ten sposób chęć przyjęcia obowiązków integratora). Pewność, że brak aktywności nie umknie uwadze integratora, mobilizowała studentów zagranicznych do przygotowania wypowiedzi i włączenia się w dyskusję oraz nie pozwalała ukryć się za wymówką o słabej znajomości języka.

Akceptację każdej grupy zyskało wprowadzenie trzech zasad: 1) przedstawianie się na początku wypowiedzi - kształtowanie poczucia odpowiedzialności za słowo (sprzyjało ważeniu słowa); 2) wypowiedzi tylko ad rem (co niejako zapobiegało wypowiedziom pustym, które często były długie, ale mimo to niczego nie wnosiły do dyskusji); 3) ograniczony czas wypowiedzi (formułowanie myśli; precyzja wypowiedzi; zapis). 
Organizacja dyskusji moderowanej, z konsekwentnie stosowaną formułą $\mathrm{z}$ udziałem integratora, zaktywizowała studentów zagranicznych, co dało im wymierne korzyści: koncentracja uwagi sprzyjała przyswajaniu wiedzy, udział zaś $\mathrm{w}$ dyskusji był źródłem satysfakcji także $\mathrm{z}$ tego względu, że inni uczestnicy zajęć uważnie słuchali wypowiedzi, nastawiając się na dopowiedzenia czy polemikę. Poprawiła się jakość dyskusji: studenci „wygadani” bardziej dbali o meritum wypowiedzi.

\section{Dobra praktyka 6: Poprawne imiona i nazwiska jako przejaw szacunku}

Imiona i nazwiska $\mathrm{z}$ innych kręgów kulturowych to obszar wrażliwy w relacjach interpersonalnych; ich zniekształcanie przeważnie odbierane jest jako lekceważenie czy brak szacunku. Konwersja zapisu imion i nazwisk z języka ukraińskiego na język polski w postaci transliteracji ${ }^{10}$, a nie transkrypcji (Polański, 2003: 107-108) $\mathrm{w}$ praktyce stwarza różne niedogodności. Studenci krajowi często widzą w tym stylizowanie na język zachodni, co im się nie podoba, a nawet wywołuje niechęć. Ponadto powtarzanie przez nauczyciela akademickiego zdrobnień imion zasłyszanych w grupie jest ryzykowne, ponieważ dana forma tego samego popularnego na Ukrainie imienia może być bliższa albo językowi ukraińskiemu (zach. Ukraina), albo rosyjskiemu (wsch. Ukraina). To samo nazwisko może mieć inny akcent w języku polskim i ukraińskim; błąd w akcencie jest odruchowo odbierany jako kaleczenie nazwiska i wspomniane lekceważenie czy brak szacunku.

Aby uniknąć wskazanych problemów, wystarczy na liście grupy konwersja imion i nazwisk w postaci transkrypcji (zapis fonetyczny) - jeśli nie z dziekanatu, to warto samemu dodać taką rubrykę. Zaznaczenie akcentu czy dodatkowych informacji (np. zdrobnienie imienia) to detale istotne $\mathrm{w}$ procesie budowania relacji. Studenci zagraniczni błyskawicznie dostrzegają i entuzjastycznie reagują na choćby najdrobniejszy przejaw starań nauczyciela akademickiego, by okazać życzliwość i chęć zrozumienia obcej kultury.

\section{Dobra praktyka 7: Komunikowanie się studenta zagranicznego na uczelni}

Komfortowa sytuacja dla studenta - nie tylko zagranicznego - jest wtedy, gdy w poszukiwaniu informacji znajduje oparcie w uczelni (samorząd studencki, tzw.

\footnotetext{
${ }^{10}$ Zasady transliteracji określa polska norma PN ISO-9:2000 Informacja i dokumentacja. Translite-
} racja znaków cyrylickich na znaki łacińskie. 
opiekun roku, kierownik studiów itd.), jednak to studenci zagraniczni uświadomili autorce, że osoba prowadząca ćwiczenia jest dla nich jak lekarz pierwszego kontaktu. Jest bowiem blisko, a kontakt $\mathrm{z}$ nią jest bezpośredni, więc po przełamaniu pierwszych lodów właśnie do niej się zwracają z różnymi pytaniami, nie tylko dotyczącymi zajęć. Większy, w porównaniu ze studentami krajowymi, dystans studentów zagranicznych do osoby prowadzącej zajęcia zmienia się, po wzroście zaufania, w większe oczekiwanie pomocy. Można odnieść wrażenie, iż dla niejednego studenta zagranicznego nauczyciel akademicki w obcym kraju jest jak rodzic zastępczy. Wrażenie to jest spotęgowane faktem, że na studia w Polsce przyjeżdżają z Ukrainy już siedemnastolatkowie.

Pomijając oczywiste indywidualne ograniczenia w zakresie wiedzy o uczelni i studiach, każdy, kto prowadzi zajęcia, może co najmniej wskazać najważniejsze obszary komunikowania się na uczelni (zob. ryc. 1). To, co jest oczywiste dla kadry i dla starszych studentów, nie jest takie dla studentów pierwszego roku nie tylko zagranicznych.

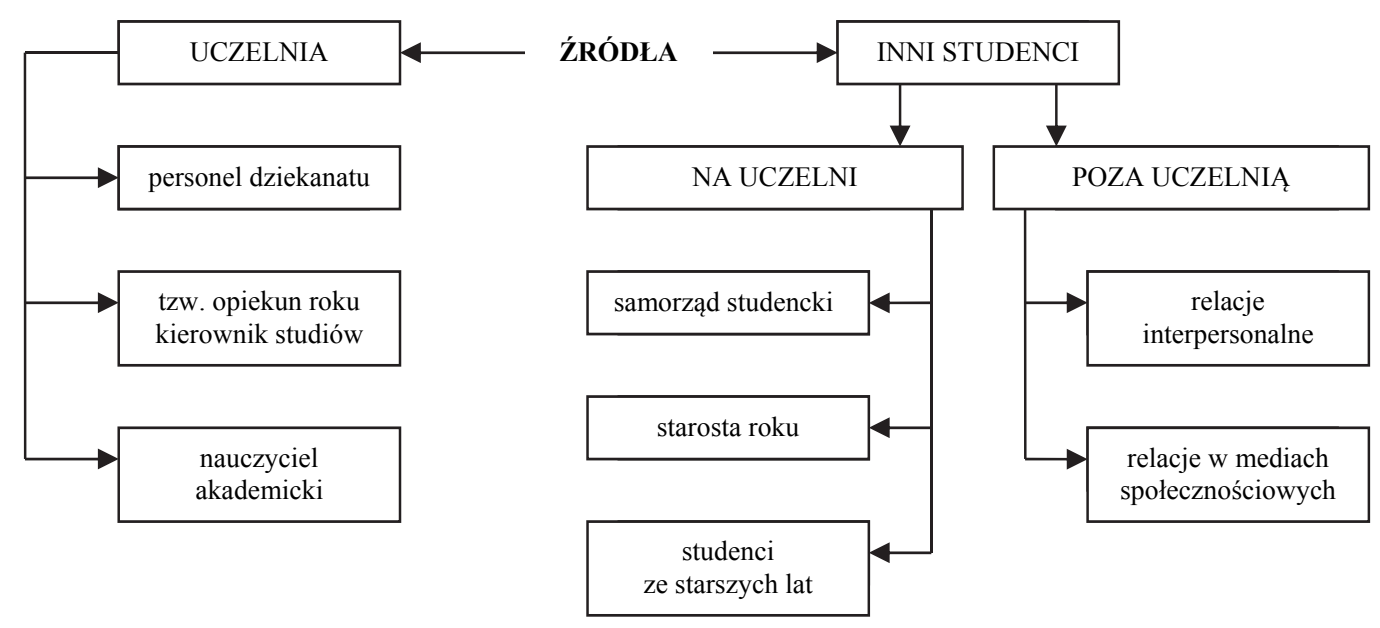

Ryc. 1. Podstawowe źródła informacji o uczelni, dla studentów zagranicznych. Źródło: opr. własne autorki na podstawie doświadczenia $\mathrm{z}$ relacji ze studentami zagranicznymi

Optymalna byłaby szczegółowa informacja na witrynie uczelni, najlepiej w obu językach, by nowi studenci nie czuli się zagubieni w nowym miejscu i w nowej roli. $\mathrm{W}$ codziennej praktyce podejście osób prowadzących zajęcia może mieć wpływ nie tylko na wizerunek uczelni, ale również na relacje podczas zajęć. 


\section{Dobra praktyka 8: Informacja o prawie i etyce}

Już najmniejsze objętościowo opracowanie jednego zagadnienia ujawniło problem różnic w Polsce i na Ukrainie: i norm prawnych, i wartości. Zgadzając się z twierdzeniem, że „(...) różnorodność sprzyja napięciom zarówno realnym, jak i w sferze symbolicznej. W konkretnej przestrzeni społecznej dochodzi bowiem do sąsiedztwa odmiennych systemów aksjologicznych i normatywnych" (Śliz, Szczepański, 2011b: 10), nie można jednak bagatelizować problemu. Typowa reakcja studentów z Ukrainy na udowodniony zarzut plagiatu w prezentacji przygotowanej na zajęcia czy w pracy zaliczeniowej to zdziwienie: „Plagiat? U nas nikt nie zwraca na to uwagi!".

Bez dociekania, jaka jest rzeczywistość i czy studenci nie przesadzają, pożądane było zalecenie im rozeznania co do traktowania plagiatu w Polsce. Na dziennikarstwie pomocne są $\mathrm{w}$ tym zakresie zajęcia z przedmiotów takich, jak prawo prasowe czy etyka dziennikarza, ale na każdym innym przedmiocie warto zwracać uwagę co najmniej na obowiązek dostosowania się do miejscowego prawa (i zalecenie poznania takichże zwyczajów).

Abstrahując od regulacji prawnych, autorka zgadza się z Wojciechem Cynarskim, który przekonuje, że „(...) gwarantem harmonijnego rozwoju społeczeństw jest kultura moralna o wysokim poziomie «etyczności». Drogą do tejże etyczności jest edukacja z głównym akcentem na pedagogikę moralności (...) konflikt wartości [wyróżnienie w oryginale - przyp. I.B.] nie jest konfliktem nierealistycznym, jak chcieliby to widzieć zwolennicy funkcjonalistycznej teorii konfliktu" (Cynarski, 2003: 204). Marek Szopski (2005: 20) zaś wyjaśnia: „W procesie komunikacji zachodzi negocjowanie i współudział w kreowaniu znaczeń. (...) Jest zrozumiałe, że porozumienie między kulturami jest tym trudniejsze, im mniejsze są szanse na wynegocjowanie wspólnie podzielanych znaczeń. (...) Stąd też porozumiewanie międzykulturowe wymaga od uczestników więcej wrażliwości i otwartości na informację zwrotną niż porozumiewanie wewnątrzkulturowe". Otwartość na informację zwrotną dotyczy, w przypadku studentów i ich nauczycieli, także sfery prawa i etyki.

\section{Dobra praktyka 9: Karta pracy zespołu}

Dbanie o efektywność pracy w zespołach jest podstawową powinnością osoby prowadzącej ćwiczenia. Specjalnie opracowana przez autorkę karta pracy zespołu była narzędziem, które służyło usprawnieniu przebiegu ćwiczeń i wsparciu zespołu podczas realizacji zadania i sprawdzało się na zajęciach. Gdy pojawili się studenci zagraniczni, karta pracy zespołu (zob. tab. 5) została zmieniona w takim stopniu, by stanowiła dla nich wsparcie i ułatwiała udział w zajęciach. 
Tabela 5. Karta pracy zespołu jako narzędzie na ćwiczeniach. Źródło: opr. własne autorki na podstawie autorskich materiałów i narzędzi na ćwiczenia

\begin{tabular}{|c|c|c|c|}
\hline Składnik karty & Treść na wydruku karty & Korzyść & Uwagi \\
\hline Identyfikacja & $\begin{array}{l}\text { data, kierunek, przedmiot, temat, grupa, miejsce } \\
\text { na nr zespołu, miejsce na punkty za zadanie } \\
\text { (wpisuje prowadzący zajęcia) }\end{array}$ & $\begin{array}{l}\text { więcej czasu na } \\
\text { zadanie }\end{array}$ & $\begin{array}{l}\text { własnoręczne wpisanie na- } \\
\text { zwisk zastępuje listę obecności }\end{array}$ \\
\hline $\begin{array}{l}\text { Dane o członkach } \\
\text { zespołu }\end{array}$ & $\begin{array}{l}\text { miejsce na nazwisko obok roli w zespole (lider, } \\
\text { sekretarz, moderator dyskusji) oraz miejsce na } \\
\text { inne role, odpowiednio do przyjętego przez } \\
\text { zespół stylu pracy }\end{array}$ & $\begin{array}{l}\text { łatwiej zorgani- } \\
\text { zować pracę ze- } \\
\text { społu }\end{array}$ & $\begin{array}{l}\text { role nie są fikcyjne; studenci } \\
\text { wiedzą, że muszą one znaleźć } \\
\text { odzwierciedlenie w zadaniu } \\
\text { (np. researcher podaje źródła) }\end{array}$ \\
\hline Zasady & $\begin{array}{l}\text { korzystanie z Internetu; czas na zadanie; czy- } \\
\text { stopis; czytelny zapis }\end{array}$ & $\begin{array}{l}\text { większa samo- } \\
\text { kontrola }\end{array}$ & przejrzystość zasad \\
\hline $\begin{array}{l}\text { Kryteria oceny } \\
\text { zadania }\end{array}$ & $\begin{array}{l}\text { na temat; kompletnie; twórczo itp. (odpowied- } \\
\text { nio do zadania) }\end{array}$ & lepsza motywacja & przejrzystość ocen \\
\hline Zadanie & treść ze slajdu & $\begin{array}{l}\text { łatwiej zrozu- } \\
\text { mieć zadanie }\end{array}$ & $\begin{array}{l}\text { ponadto wskazówki technicz- } \\
\text { ne (np.: zalecana forma tabel- } \\
\text { ki); ułatwiony zapis (np.: } \\
\text { punkty; równoważniki zdań) }\end{array}$ \\
\hline Przykład & odpowiednio do treści zadania & $\begin{array}{l}\text { latwiej wykonać } \\
\text { zadanie }\end{array}$ & walor inspiracji \\
\hline Forma & $\begin{array}{l}\text { odpowiednio do zadania (np. jeśli wymagane są } \\
\text { trzy pozycje z uzasadnieniem, to na karcie są: } \\
\text { trzy punkty, wyrazy „Pozycja”, „Uzasadnienie”) }\end{array}$ & $\begin{array}{l}\text { łatwiej wykonać } \\
\text { zadanie }\end{array}$ & $\begin{array}{l}\text { wymierne wsparcie istotne } \\
\text { przy ograniczeniu czasu }\end{array}$ \\
\hline
\end{tabular}

Dzięki dbałości o detale zespoły miały komfort pracy, ponieważ nie było potrzeby dopytywania się o nie. Sama karta zaś przyzwyczajała studentów do standardu wykonywania zadań, a ponadto ułatwiała pracę. Wskazanie możliwości ułatwionego (w punktach czy równoważnikach zdań) zapisu efektów pracy zespołu zaowocowało wyższą jakością pracy studentów zagranicznych, gdy to właśnie oni pełnili funkcję sekretarza. W innych przypadkach taka forma zapisu ułatwiała studentom z zagranicy odczytanie i zrozumienie treści.

Studenci zagraniczni doceniali takie narzędzie używane na ćwiczeniach, na kolejnych zajęciach dopytując się o dostępność karty pracy zespołu. Zawarte na karcie pracy zespołu dodatkowe informacje, wraz z uproszczeniem zapisu i podaniem przykładu, były korzystne także dla wielu studentów krajowych.

\section{Dobra praktyka 10: Przyjazny język obcy}

Ta dobra praktyka jest ostatnia, ale wcale nie najmniej ważna. Zaskoczeniem dla autorki była dość typowa (nie)znajomość języka polskiego i różne konsekwencje takiego stanu rzeczy. Formalnie każdy student ma certyfikat znajomości języka 
na poziomie umożliwiającym podjęcie studiów, na zajęciach zaś okazywało się, że taki dokument $\mathrm{w}$ wielu przypadkach nie odzwierciedla stanu faktycznego i zdarzają się sytuacje, gdy student nie potrafi się przedstawić i prosi o komunikowanie się jeśli nie w jego języku, czyli ukraińskim, to w języku rosyjskim. Takie oczekiwania bywały wzmacniane łamaniem przez niektórych wykładowców zasady prowadzenia zajęć w języku polskim.

Dominacji języka rosyjskiego na Ukrainie dowodzą dane dotyczące mediów (zwłaszcza telewizji i Internetu) oraz wydawnictw książkowych (Szeptycki, 2014). Według regulacji ustawowych język rosyjski to język regionalny w prawie połowie regionów Ukrainy; „(...) połowa Ukraińców uważa język ukraiński za ojczysty, a rosyjski 29 procent. 1/5 wymienia dwa języki. Na co dzień, szczególnie w większych miastach, poza zachodem kraju, używany jest jednak rosyjski" (Pogorzelski, 2012).

W tym miejscu należy dodać, że jednym z zadań dla uczelni jest „Rozwijanie kompetencji językowych studentów, doktorantów, pracowników naukowych" ([b.a.], Kierunki działań... s. 17); w „Programie umiędzynarodowienia szkolnictwa wyższego" zapisano: "Język angielski jest linqua franca współczesnej nauki, zatem kadra oraz studenci powinni biegle się nim posługiwać" ([b.a.], Kierunki działań... s. 17). Na razie jednak można wątpić w przydatność dla studentów z Ukrainy zajęć w języku angielskim; w praktyce autorki tylko jedna studentka, po anglistyce, zgodziła się sięgnąć do źródeł anglojęzycznych.

Wspólne mieszkanie $\mathrm{z}$ rodakami nie sprzyjało podnoszeniu poziomu znajomości języka polskiego, a mimo wyboru dziennikarstwa jako kierunku studiów nie skłaniało do zainteresowaniu mediami polskojęzycznymi. Skutkiem kontaktu z mową ulicy, a nie z językiem literackim i poprawną polszczyzną, było błyskawiczne przyswajanie powszechnych błędów krajowców.

Wspólnota językowa ukraińskiego i polskiego może być utrudnieniem w komunikowaniu się - pułapkę stanowią słowa, które są tzw. fałszywymi przyjaciółmi (np.: „багато” to nie „bogato”, ale „dużo”; „казати” - nie „kazać”, tylko „mówić"). Wielu studentów zagranicznych wpada w tę pułapkę, nic więc dziwnego, że po dwóch-trzech latach wspólnych studiów niektórzy studenci krajowi reagują podobnie jak we wspomnianym przypadku naboru na specjalizację telewizyjną. Powodem jest wysoka ocena prac dyplomowych tych studentów zagranicznych, którzy oddają niesamodzielną pracę. Prace tłumaczone na język polski są lepiej napisane niż pozostałe, ponieważ profesjonalny tłumacz ma wyższy poziom kompetencji językowych niż przeciętny student-krajowiec. Nierealny jest, co oczywiste, podział roku na grupy według poziomu znajomości języka polskiego; szczególna odpowiedzialność spoczywa na promotorach, którzy $\mathrm{w}$ toku bieżącej pracy z każdym dyplomantem mogą zorientować się w poziomie samodzielności studenta. 
Ze względu na liczne ograniczenia możliwości rozwoju kompetencji językowych zajęcia na uczelni mogą mieć wartość dodatkową. Dla studentów zagranicznych, zainteresowanych podnoszeniem poziomu znajomości języka polskiego, znaczenie mają kompetencje językowa i kultura języka osoby prowadzącej zajęcia; oprócz precyzji wypowiedzi i logiki wywodu ceniona jest gotowość wyjaśnienia słów trudnych i/lub wskazania łatwiejszych synonimów. Liczy się także reakcja na prośbę studenta zagranicznego o bieżące korygowanie błędów językowych; prośbę dobrze przyjmowano w grupie mieszanej, jeśli osoba prowadząca zajęcia zaproponowała wprowadzenie - ze względu na kierunek studiów, czyli dziennikarstwo - zwyczaju korygowania błędów językowych zarówno u studentów zagranicznych, jak i krajowych.

Notabene raport ekspercki Komisji Europejskiej zaleca wprowadzenie programu nauki tak zwanego przybranego języka własnego (Ratajczak, 2012), co miałoby wzbudzić zainteresowanie językami spoza grupy najpopularniejszych języków międzynarodowych, a w efekcie ułatwić komunikację między obywatelami różnych narodowości.

\section{Podsumowanie}

Jak świadomość różnic jest niezbędna do funkcjonowania w społeczeństwie wielokulturowym, tak podobna świadomość jest niezbędna dla efektywnej edukacji - ale $\mathrm{w}$ połączeniu $\mathrm{z}$ umiejętnością znajdowania rozwiązań nieuchronnych problemów. Przedstawione dobre praktyki mają walor poznawczy: mogą stanowić punkt wyjścia dla rozważań o wielokulturowości w środowisku akademickim. Ponadto umożliwiają identyfikację typowych problemów, pozostawiając miejsce na wypracowanie własnego rozwiązania, odpowiednio do specyfiki uwarunkowań na poszczególnych uczelniach.

Nie ma prostej odpowiedzi na pytanie, czy wielokulturowość jest źródłem konfliktów i czy w jednym państwie realna jest koegzystencja przedstawicieli różnych kultur (Śliz, Szczepański, 2011a). Trudno również orzec, w jakim zakresie możliwe jest takie współistnienie w szkołach wyższych. Ale gdzie, jeśli nie tam? Dobre praktyki mogą być podpowiedzią, jak to robić.

\section{Literatura}

Benedyktowicz Z. (2000). Portrety „obcego”. Od stereotypu do symbolu. Kraków.

Cynarski W.J. (2003). Globalizacja a spotkanie kultur. Rzeszów.

Czerniejewska I. (2013). Edukacja wielokulturowa: działania podejmowane w Polsce. Toruń. 
Dąbrowska A., Burzyńska-Kamieniecka A. (red.). (2006). Wielokulturowość w języku, t. 18 „Język a Kultura". Wrocław.

Golka M. (2010). Imiona wielokulturowości. Warszawa.

Mucha J. (2004). Kultura dominująca jako kultura obca. Mniejszości kulturowe a grupa dominująca we wspótczesnej Polsce. [W:] I. Machaj (wybór i wstęp). Małe struktury społeczne. Lublin.

Omyła-Rudzka M. (2015). Stosunek do innych narodów. Komunikat $z$ badań CBOS. Warszawa. http://www.cbos.pl/SPISKOM.POL/2015/K_014_15.PDF.

Pogorzelski P. (2012). Rosyjski językiem urzędowym na Ukrainie. http://www.polskieradio.pl/ 5/3/Artykul/662137,Rosyjski-jezykiem-urzedowym-na-Ukrainie.

Ratajczak M. (2012). Dialog międzykulturowy w mediach. Przypadek europejskiego roku dialogu międzykulturowego w 2008 roku w Polsce. „Pogranicze. Studia Społeczne”, t. 20, http://repozy torium.uwb.edu.pl.

Siwińska B. (2012). Myślenie do przodu. http://www.perspektywy.pl/index.php?option=com_ content\&task=view\&id=3859\&Itemid=832, dostęp: 16.10.2016.

Siwińska B. (2015). Już ponad 46 tysięcy studentów zagranicznych w Polsce. http://www.perspek tywy.pl/portal/index.php?option=com_content\&view=article\&id=2221:juz-ponad-46-tysiecystudentow-zagranicznych-w-polsce\&catid $=24 \&$ Itemid $=119$.

Szczygieł K. (2016). Pół-Polki, średnio-Polacy, Wariograf.org - blog dziennikarski studentów UW, https://wariograf.org/2016/01/10/147/

Szeptycki A. (2014). Pozycja jezzyka rosyjskiego na Ukrainie. [W:] A. Szeptycki. Ukraina wobec Rosji. Studium zależności. Warszawa.

Szkolnictwo wyższe w Polsce 2013, Ministerstwo Nauki i Szkolnictwa Wyższego, http://www.nauka. gov.pl/g2/oryginal/2013_07/0695136d37bd577c8ab03acc5c59a1f6.pdf

Szmyd K. (2003). Z tradycji polskiej pedagogiki wielokulturowej. „Kwartalnik Pedagogiczny” nr 4/190, s. 25-40.

Śliz A., Szczepański M. (2011a). Wielokulturowość: perspektywa konfliktu czy szansa koegzystencji?. [W:] A. Śliz, M.S. Szczepański (red.). Wielokulturowość: konflikt czy koegzystencja? Warszawa.

Śliz A., Szczepański M.S. (2011b). Wielokulturowość i jej socjologiczny sens. Festival Caravan czy wielokulturowe Street Party?. „Studia Socjologiczne” nr 4/203, s. 7-25.

Trzciński R. (2015). Zagraniczni studenci - czy potencjalni uczestnicy polskiego rynku pracy? [W:] J. Konieczna-Sałamatin (red.). Imigranci o wysokich kwalifikacjach na polskim rynku pracy. Raport z badań 2014-2015. Warszawa.

Znaniecki F. (1931). Studia nad antagonizmem wobec obcych. „Przegląd Socjologiczny” t. 1. 